\title{
Flooding in the Amargosa River Drainage Basin, February 23-24, 1998, Southern Nevada and Eastern California, including the Nevada Test Site
}

\section{Introduction}

The Amargosa River drainage basin is about 100 miles northwest of Las Vegas, Nev., and includes part of the Nevada Test Site (NTS). During February 23-24, 1998, a regional storm produced 1.10-2.81 inches of measured precipitation, which resulted in minor flooding throughout the Amargosa River drainage basin. Streamflow from this storm was largely derived from four tributaries: Topopah, Fortymile, and Beatty Washes, which originate on NTS, and Carson Slough, which drains the Ash Meadows area downstream from NTS (Fig. 1). Streamflow from these tributaries caused the Amargosa River to flow continuously from its headwaters on Pahute Mesa to its terminus in Death Valley (Fig. 1).

U.S. Geological Survey (USGS) personnel estimated peak streamflows at more than 30 locations and compiled precipitation measurements within the Amargosa River drainage basin to characterize the February 23-24, 1998, flooding (Tables 1 and 2). The data collected are compared with similar data from the March 10-11, 1995, flooding of the Amargosa River. Cumulative streamflow volumes for the 1995 and 1998 storm runoffs cannot be compared because most of the streamflow gaging stations operated in 1995 were discontinued prior to the 1998 flood.

The USGS, in cooperation with the U.S. Department of Energy, monitors streamflow in southern Nevada and eastern California through a network of streamflow gaging stations and streamflow measurements at miscellaneous sites. Data provided by this network are being used to help with the characterization of Yucca Mountain, near NTS, as a potential repository for long-term storage of the Nation's high-level nuclear waste. Major questions arising from the Yucca Mountain site-characterization studies are whether, under the present climatic regime, Fortymile Wash is capable of flowing to the Amargosa River, and whether Amargosa River is similarly capable of flowing from its source to Death Valley.

The Amargosa River Basin includes 5,500 $\mathrm{mi}^{2}$ (Grasso, 1996, table 1) of rugged arid terrain in southwestern Nevada and southeastern California (Fig. 1). Basin relief is approximately 8,000 feet, ranging from about 7,700 feet above sea level at Pahute Mesa, Nev., to about 300 feet below sea level at Badwater Basin in Death Valley, Calif. The river basin is sparsely populated and includes small rural communities, mining operations, agricultural areas, Ash Meadows National Wildlife Refuge, Death Valley National Park, and government research facilities at NTS.

The Amargosa River is atypical of most North American rivers because it seldom flows; runoff is infrequent because much of the basin receives less than $6 \mathrm{in} / \mathrm{yr}$ of precipitation (Hardman, 1965). The river is normally dry except for several short reaches that flow seasonally and are fed by springs. The major tributaries to the northern reach of the Amargosa River are Thirsty Canyon wash and Beatty Wash, which drain the northwestern part of NTS (Fig. 1). Major tributaries to the central reach of the Amargosa River are Fortymile Wash, Topopah Wash, and Carson Slough (Fig. 1). Fortymile Wash drains the southern part of Pahute Mesa, the western part of Jackass Flats, and the eastern slopes of Yucca Mountain. Topopah Wash drains the eastern part of Jackass Flats. Carson Slough, near Death Valley Junction, is a network of shallow incised channels that drain the Ash Meadows area.
Downstream from Alkali Flat, in the southern reach, the Amargosa River channel generally is well defined from Eagle Mountain to Dumont Sand Dunes, Calif. Upstream from Dumont Sand Dunes, small thermal springs near Shoshone and Tecopa, Calif., contribute flow to the Amargosa River. Springs also add to river flow in the canyon reach between Tecopa and Dumont Sand Dunes. Downstream from Dumont Sand Dunes, the Amargosa River flows through southern Death Valley to its terminus at the Badwater Basin salt pan.

\section{February 1998 Storm and Streamflow}

Precipitation monitoring sites operated by the National Weather Service (NWS), U.S. Fish and Wildlife Service, and National Oceanic Atmospheric Administration (NOAA) recorded 29 to 54 percent of total February precipitation from a regional storm system within 48 hours beginning the morning of February 23, 1998 (Table 1). USGS personnel at NTS reported streamflow in small washes, such as Split and Pagany (which partly drain the eastern slope of Yucca Mountain), during the morning of February 23 (Fig. 1). By mid-afternoon, Yucca, Topopah, and Fortymile Washes also were reported flowing. Fortymile Wash was flowing over roads on NTS near Yucca Mountain (Daniel Soeder, U.S. Geological Survey, written commun., 1998). Peak streamflow estimates for Fortymile and Topopah Washes (Table 2) and downstream field observations indicate those streams flowed from NTS and joined the Amargosa River. On the basis of field observations and data collected from continuous surface-water monitoring sites, streamflow durations generally ranged from 12 to 36 hours and varied according to tributary subbasin sizes. Channel erosion by streamflow was considered minimal in the large tributaries of Fortymile, Topopah, and Beatty Washes, but was more severe in some smaller tributaries such as Pagany, Yucca, Split, and Dune Washes. Roads within these small drainages were nearly impassable because of erosion.

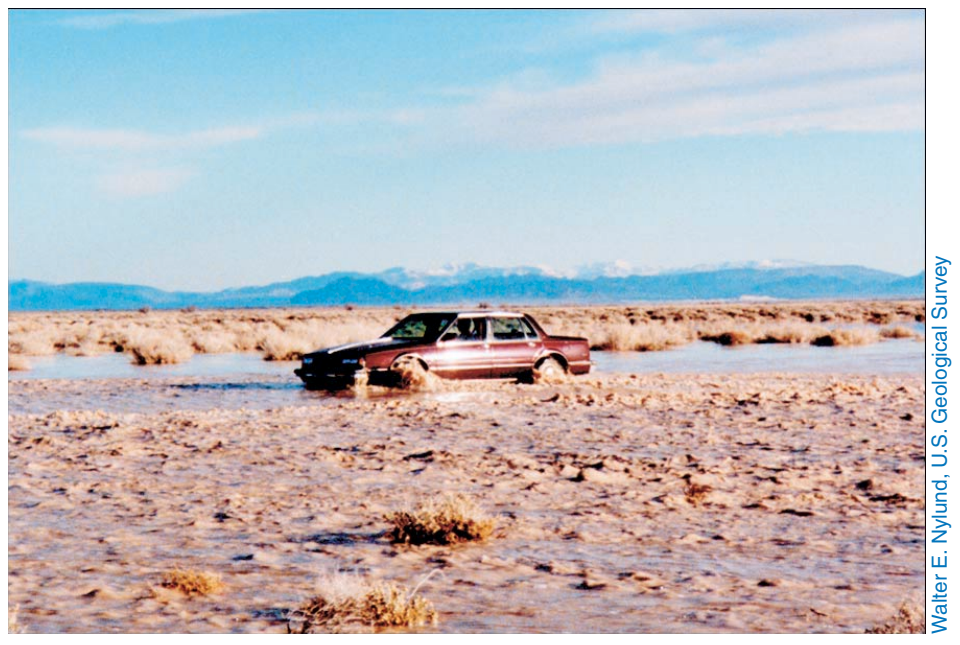

Carson Slough, State Line Road near Death Valley Junction, California, looking north, February 25, 1998. 


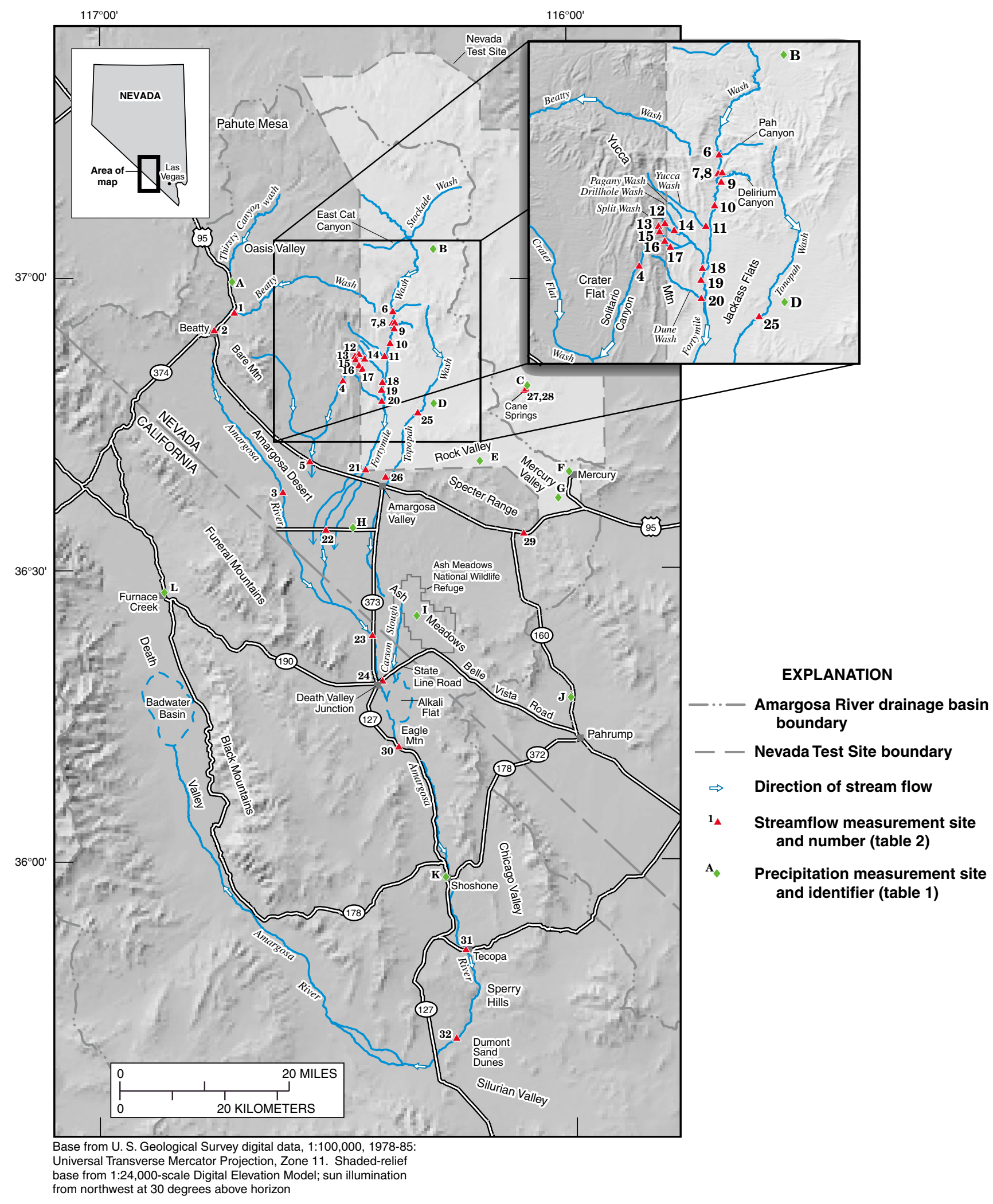

Figure 1. Geographic setting and flow paths of the Amargosa River drainage basin during the February 23-24, 1998, flood.

Field observations off NTS indicated that Amargosa River flow lasted for several days near Eagle Mountain and southward near Dumont Sand Dunes (Fig. 1). Although not quantifiable because of multiple, poorly confined channels, field observations indicated that runoff from the Ash Meadows area contributed substantial streamflow (through Carson Slough) to the central reach of the Amargosa River. Prolonged runoff from Ash Meadows probably was amplified because precipitation prior to late February recharged the soil mantle.
Thereby, infiltration losses from the late-February storm were reduced. Flows over roads were observed where U.S. Highway 95 crosses Fortymile Wash, in the Amargosa Farms, State Line Road area, and at several river crossings on California State Highway 127. The combined result of widespread and prolonged storm runoff throughout the Amargosa River Basin was persistent streamflow that contributed to the formation of a small lake on the normally dry and barren Badwater Basin salt pan at the river terminus in Death Valley. 
Table 1. Precipitation for March 1995 and February 1998 floods, Amargosa River Basin, Nevada-California [Abbreviations and symbol: e, estimated; Nev., Nevada; NTS, Nevada Test Site; --, not available]

Note: Trace amounts of precipitation and snowfall are not figured into totals.

\begin{tabular}{|c|c|c|c|c|c|c|c|}
\hline \multirow{2}{*}{$\begin{array}{c}\text { Site } \\
\text { identifier } \\
\text { (fig. 1) }\end{array}$} & \multirow{2}{*}{ Station name } & \multicolumn{2}{|c|}{$\begin{array}{l}\text { Precipitation (inches) } \\
\text { in March } 1995\end{array}$} & \multirow{2}{*}{$\begin{array}{c}\text { Percent of } \\
\text { total for } \\
\text { March 10-11, } \\
1995\end{array}$} & \multicolumn{2}{|c|}{$\begin{array}{l}\text { Precipitation (inches) } \\
\text { in February } 1998\end{array}$} & \multirow{2}{*}{$\begin{array}{c}\text { Percent of } \\
\text { total for } \\
\text { February } \\
23-24, \\
1998\end{array}$} \\
\hline & & March 10-11 & $\begin{array}{l}\text { March } \\
\text { total }\end{array}$ & & $\begin{array}{c}\text { February } \\
23-24\end{array}$ & $\begin{array}{c}\text { February } \\
\text { total }\end{array}$ & \\
\hline A & Beatty, Nev. ${ }^{1,4}$ & 2.36 & 3.50 & 67 & 1.68 & 4.47 & 38 \\
\hline $\mathrm{B}$ & Fortymile Canyon, NTS ${ }^{2}$ & 3.98 & 5.40 & 74 & 2.10 & 5.15 & 41 \\
\hline $\mathrm{C}$ & Cane Springs, NTS ${ }^{2}$ & 1.38 & 2.63 & 52 & $\mathrm{e} 2.20$ & e 6.04 & 36 \\
\hline $\mathrm{D}$ & Jackass Flats, NTS ${ }^{2}$ & 1.79 & 2.48 & 72 & $\mathrm{e} 2.10$ & $\mathrm{e} 6.26$ & 34 \\
\hline $\mathrm{E}$ & Rock Valley, NTS ${ }^{2}$ & 1.53 & 2.61 & 59 & 2.81 & 5.97 & 47 \\
\hline $\mathrm{F}$ & Mercury, NTS ${ }^{2}$ & .68 & 1.60 & 42 & 2.17 & 4.10 & 53 \\
\hline $\mathrm{G}$ & Desert Rock, NTS ${ }^{2}$ & .81 & 2.39 & 34 & 2.52 & 4.64 & 54 \\
\hline $\mathrm{H}$ & Amargosa Farms, Nev. ${ }^{1,4}$ & .52 & .94 & 55 & 1.76 & 3.69 & 48 \\
\hline I & Ash Meadows, Nev. ${ }^{3}$ & -- & -- & - & 1.40 & 3.16 & 44 \\
\hline $\mathrm{J}$ & Pahrump, Nev. ${ }^{1}$ & -- & -- & -- & 1.42 & 3.32 & 43 \\
\hline $\mathrm{K}$ & Shoshone, Calif. ${ }^{1,4}$ & 0 & .45 & 0 & 1.10 & 3.84 & 29 \\
\hline $\mathrm{L}$ & Death Valley, Calif. ${ }^{1,4}$ & .24 & .31 & 77 & 1.10 & 2.31 & 48 \\
\hline
\end{tabular}

${ }^{1}$ Ernie Cobb, National Weather Service, written commun., 1998.

${ }^{2}$ Raymond D. Dennis, National Oceanic Atmospheric Administration, written commun., 1998.

${ }^{3}$ David St. George, U.S. Fish and Wildlife Service, oral commun., 1998.

${ }^{4}$ Dorothy Miller, Desert Research Institute, oral commun., 1998.

\section{Comparison of 1995 and 1998 Floods}

The floods of March 1995 and February 1998 have similarities and differences. Similarities include larger-than-normal snowpacks during both years on Pahute Mesa and surrounding mountains (Beck and Glancy, 1995; Raymond Dennis, National Oceanic and Atmospheric Administration, oral commun., 1998). Both floods were the result of regional storms that contributed a substantial quantity of precipitation to the river basin over a relatively short time. Also, both floods may have occurred during periods of the atmospheric and oceanic phenomenon known as "El Nino" (Desert Research Institute, 1998; National Oceanic and Atmospheric Administration, 1998). During both floods, surface water from NTS flowed to the Amargosa River mainly by way of Fortymile Wash, and road overflows were observed at similar locations. Neither lower Crater Flat nor Solitario Canyon (Fig. 1) contributed streamflow to the Amargosa River during the floods of March 1995 and February 1998.

Differences between the two floods, however, also were apparent. For example, the flood of March 1995 was the result of precipitation, of relatively short duration, that occurred mainly in the higher altitudes near Yucca Mountain. Snowpack melting, which resulted from precipitation at these higher altitudes, probably contributed significantly to the peak streamflows in Beatty and Fortymile Washes and their associated tributaries (David A. Beck, U.S. Geological Survey, oral commun., 1998). In Fortymile Wash, a peak streamflow of about 3,000 ft $3 / \mathrm{s}$ (Table 2) severely scoured and eroded the channel and caused extensive road damage on NTS and to U.S. Highway 95 (Beck and Glancy, 1995).

In contrast, the February 1998 flooding was attributed to persistent, widespread precipitation, over several days, which eventually caused streamflow in most major tributaries to Fortymile Wash and the Amargosa River. Although snowpack accumulation was observed at higher altitudes within the region during February 1998, snowpack melting was not a major factor during the 1998 flood (David A. Beck, U.S. Geological Survey, oral commun., 1998). Peak streamflows generally were lower in the northern (higher altitude) reach of the Amargosa River drainage basin, but higher in the central and southern (lower altitude) reaches of the drainage basin.
Major streamflow from NTS during the March 1995 flood was observed only in Beatty and Fortymile Washes. During the February 1998 flood, Topopah Wash also flowed off NTS (Table 2). Based on peak-flow estimates and observations of channel scour and fill, streamflows were greater in Beatty and Fortymile Washes during March 1995 than February 1998; however, streamflows were greater in several small washes including Dune, Yucca, Cane Springs, and Split (Table 2) during February 1998 than March 1995. Durations of streamflows also differed between the two floods; the February 1998 streamflows in washes on NTS lasted 12 to 36 hours, whereas the March 1995 streamflows lasted only 10 to 12 hours.

Runoff from the Ash Meadows area played an important role in sustaining streamflow in the central and southern reaches of the Amargosa River in February 1998. Near-peak streamflow discharge was observed at Carson Slough draining into Alkali Flat approximately 24 hours after flow completely ceased in Fortymile Wash and in the Amargosa River upstream from Nevada State Highway 373 (David A. Beck, U.S. Geological Survey, oral commun., 1998). Overall, the February 1998 flood sustained streamflow over a longer duration throughout the entire Amargosa River drainage basin than did the March 1995 flood.

\section{Summary}

The 1995 streamflow was dominated by high-magnitude runoff of relatively short duration in Beatty and Fortymile Washes, probably enhanced by localized precipitation on snowpack in the upper altitudes of NTS. In 1998, sustained regional precipitation caused lower magnitude streamflows of longer duration in Fortymile Wash, Amargosa River, and their major tributaries. In both floods, much or all of Fortymile Wash and the Amargosa River flowed simultaneously. In March 1995, water in Fortymile and Beatty Washes flowed off NTS; in February 1998, water in Topopah Wash also flowed off NTS. In 1995 and 1998, the Amargosa River flowed from its headwaters to its terminus in Death Valley. Both the 1995 and 1998 floods indicate, therefore, that the Amargosa River, with contributing streamflow from one or more among Beatty, Fortymile, and Topopah Washes, has the potential to transport dissolved and particulate material well beyond the boundary of NTS and the Yucca Mountain area during periods of moderate to severe streamflow. 
Table 2. Peak-flow estimates for selected sites in tributaries and reaches of the Amargosa River Basin, Nevada-California [Site number is assigned in downstream order from uppermost location. Abbreviations and symbols: Nev., Nevada; Calif., California; nd, not determined; $\mathrm{ft}^{3} / \mathrm{s}$, cubic feet per second; $\mathrm{mi}^{2}$, square miles; <, less than]

\begin{tabular}{|c|c|c|c|c|c|c|}
\hline \multirow{2}{*}{$\begin{array}{c}\text { Site } \\
\text { no. } \\
\text { (fig. 1) }\end{array}$} & \multicolumn{2}{|r|}{ Gaging station } & \multirow{2}{*}{$\begin{array}{c}\text { Drainage } \\
\text { area } \\
\left(\mathrm{mi}^{2}\right)\end{array}$} & \multicolumn{2}{|c|}{ Peak discharge $\left(\mathrm{ft}^{3} / \mathrm{s}\right)$} & \multirow{2}{*}{$\begin{array}{l}\text { Years of } \\
\text { streamflow } \\
\text { record }\end{array}$} \\
\hline & Number & Name & & $\begin{array}{c}\text { March } \\
1995\end{array}$ & $\begin{array}{c}\text { February } \\
1998\end{array}$ & \\
\hline \multicolumn{7}{|c|}{ Nevada Test Site } \\
\hline 6 & 102512495 & Pah Canyon Wash above Fortymile Wash Confluence & 6.28 & nd & 90 & 1998 \\
\hline 7 & 102512496 & Unnamed Tributary to Fortymile Wash North of Delirium Canyon & 1.14 & nd & 180 & 1998 \\
\hline 8 & 102512497 & Delirium Canyon Wash above Fortymile Wash Confluence & 2.37 & nd & 120 & 1998 \\
\hline 9 & 102512499 & Unnamed Tributary to Fortymile Wash South of Delirium Canyon & .81 & nd & 70 & 1998 \\
\hline 10 & 10251250 & Fortymile Wash at Narrows & 258 & 3,000 & 200 & $1983-97,1998$ \\
\hline 11 & 10251252 & Yucca Wash near Mouth & 17.0 & 0 & 220 & $1982-95,1998$ \\
\hline 12 & 102512531 & Pagany Wash near the Prow & .47 & 60 & 20 & $1994-95,1998$ \\
\hline 13 & 102512533 & Pagany Wash \#1 near Well UZ-4 & .82 & 60 & 17 & $1993-95,1998$ \\
\hline 14 & 102512535 & Drillhole Wash above UZ-1 & .68 & 30 & $<4.0$ & $1994-95,1998$ \\
\hline 15 & 1025125356 & Wren Wash at Yucca Mountain & .23 & 30 & $<5.0$ & $1994-95,1998$ \\
\hline 16 & 102512537 & Split Wash below Quac Canyon Wash & .33 & 11 & 13 & $1993-95,1998$ \\
\hline 17 & 1025125372 & Split Wash at Antler Ridge & 2.35 & nd & $<2.0$ & $1993-95,1998$ \\
\hline 18 & 10251254 & Drillhole Wash at Mouth & 16.3 & $<0.1$ & 25 & $1983-95,1998$ \\
\hline 19 & 10251255 & Fortymile Wash near Well J-13 & 304 & 3,000 & 200 & $1983-97,1998$ \\
\hline 20 & 10251256 & Dune Wash near Busted Butte & 6.77 & $<3.0$ & ${ }^{1}$ nd & $1982-95,1998$ \\
\hline 25 & 10251260 & Topopah Wash at Little Skull Mountain & 104 & $<1.5$ & 30 & $1984-95,1998$ \\
\hline 27 & 10251265 & Cane Springs Wash near Cane Springs & 8.36 & $<5.0$ & 110 & $1984-95,1998$ \\
\hline 28 & 102512654 & Cane Springs Tributary below Skull Mountain & 2.29 & 15 & $<5.0$ & $1992-95,1998$ \\
\hline \multicolumn{7}{|c|}{ Sites off the Nevada Test Site } \\
\hline 1 & 10251215 & Beatty Wash near Beatty, Nev. & 94.6 & 900 & 30 & $1989-95,1998$ \\
\hline 2 & 10251217 & Amargosa River at Beatty, Nev. & 458 & 1,000 & 90 & $1993-95,1996-98$ \\
\hline 3 & 10251225 & Amargosa River at Big Dune near Amargosa Valley, Nev. & 842 & nd & 20 & 1998 \\
\hline 4 & 10251233 & Solitario Canyon at Mouth near Yucca Mountain, Nev. & 4.14 & 0 & 0 & 1995,1998 \\
\hline 5 & 10251235 & Crater Flat Wash above Highway 95 near Amargosa Valley, Nev. & 157 & 0 & 0 & 1995,1998 \\
\hline 21 & 10251258 & Fortymile Wash near Amargosa Valley, Nev. & 316 & 21,200 & 2340 & $1983-98$ \\
\hline 22 & 102512585 & Fortymile Wash at Amargosa Farms, Nev. & 325 & nd & ${ }^{3} 90$ & 1998 \\
\hline 23 & 10251259 & Amargosa River at Highway 127 near Calif.-Nev. State Line & 1,542 & 27 & 30 & $1993-95,1998$ \\
\hline 24 & 102512597 & Amargosa River at Death Valley Junction, Calif. & 1,567 & $<5.0$ & 60 & 1995,1998 \\
\hline 26 & 10251261 & Topopah Wash at Highway 95 near Amargosa Valley, Nev. & 150 & nd & 20 & 1998 \\
\hline 29 & 10251270 & Amargosa River Tributary near Mercury, Nev. & 110 & 0 & 25 & $\begin{array}{l}1963-81, \\
1984-95,1998\end{array}$ \\
\hline 30 & 10251280 & Amargosa River near Eagle Mountain below Death Valley Junction, Calif. & 2,632 & 100 & 190 & $1990-95,1998$ \\
\hline 31 & 10251300 & Amargosa River at Tecopa, Calif. & 3,090 & 170 & 250 & $\begin{array}{l}\text { 1961-83, } \\
1991-95,1998\end{array}$ \\
\hline 32 & 10251375 & Amargosa River at Dumont Sand Dunes near Death Valley, Calif. & 3,284 & nd & 200 & 1998 \\
\hline
\end{tabular}

${ }^{1}$ Road repair and grading destroyed all high-water marks prior to peak-streamflow estimates, but it is believed by reconnaissance teams that runoff may have been substantial to cause such extensive road damage.

${ }^{2}$ Includes peak streamflow estimates in bypass channel of $300 \mathrm{ft}^{3} / \mathrm{s}$ (March 1995) and $7.0 \mathrm{ft}^{3} / \mathrm{s}$ (February 1998).

${ }^{3}$ Total of peak streamflow estimates in three principal channels.

\section{Selected References}

Beck, D.A., and Glancy, P.A., 1995, Overview of runoff of March 11, 1995, in Fortymile Wash and Amargosa River, southern Nevada: U.S. Geological Survey Fact Sheet FS-210-95, 4 p.

Desert Research Institute, 1998, Western Regional Climate Center theme page: accessed August 3, 1998, on the World Wide Web at URL <http://www.wrcc.dri.edu/cgi-bin/elnino1.pl>.

Grasso, D.N., 1996, Hydrology of modern and late Holocene lakes, Death Valley, California: U.S. Geological Survey Water-Resources Investigations Report 95-4237, $54 \mathrm{p}$

Hardman, George, 1965, Nevada precipitation map: University of Nevada Agricultural Experimentation Bulletin 183, 57 p.

Laczniak, R.J., Cole, J.C., Sawyer, D.A., and Trudeau, D.A., 1996, Summary of hydrogeologic controls on ground-water flow at the Nevada Test Site, Nye County, Nevada: U.S. Geological Survey Water-Resources Investigations Report 96-4109, 59 p.

National Oceanic Atmospheric Administration, 1998, El Nino theme page: accessed August 3, 1998, on the World Wide Web at URL $<$ http://www.pmel.noaa.gov/toga-taol/el-nino-story.html>.

National Weather Service, 1998, Las Vegas home page: accessed August 3, 1998, on the World Wide Web at URL <http://nimbo.wrh.noaa.gov/Lasvegas> [last updated June 9, 1998].

U.S. Geological Survey, 1993-97, Water resources data, Nevada, water years 1992-96: U.S. Geological Survey Water-Data Reports, NV-92-1 to NV-96-1 (published annually).

—Daron J. Tanko and Patrick A. Glancy

For further information contact:

Public Information Assistant GS-W-NVpublic-info@usgs.gov URL: http://nevada.usgs.gov telephone: (775) 887-7649
U.S. Geological Survey 333 W. Nye Lane Carson City, NV 89706 